\title{
Wisely Using Gadget for Parents in Family Environment Campaign Design
}

\author{
Hasna Budi Ariani ${ }^{1}$, Gandara Permana ${ }^{2}$
}

${ }^{1}$ Fakultas Industri Kreatif, Telkom University, Bandung, Indonesia

${ }^{2}$ Fakultas Industri Kreatif, Telkom University, Bandung, Indonesia

hasnabudi@gmail.com (hasna budi ariani), gandarap@telkomuniversity.ac.id (gandara permana)

\begin{abstract}
A gadget is a device that functions primarily to ease human communication. However, nowadays there pretty many people that using gadget unwisely, they are too busy with their own gadget and tends to be neglected their environment roughly. This behavior also occurs in the family environment, which caused some negative effects. One of which is causing increasingly difficult direct interaction between family members. Based on existing research, it required an un- derstanding for the parents in order to understand the negative impact of using gadget excessively. Therefore, it will rise their awareness to change their behavior, so they will understand and become wiser to choose the time when using gadget. This study uses qualitative methods by collecting data through observation, interview, questionnaire, and using the com- munication strategy design Facet Model of Effects afterwards. The consideration of creative strategy is packaged in a visual form that has focus on the child's feeling when they parents uses gadget too much in front of them, as well as using various medias, among posters, video, and other supporting medias.
\end{abstract}

Keywords Gadget, Parents, Children, Family

\section{Introduction}

In this globalization era, gadget cannot be separated from human life. Gadget is a device that appears due to advances in technology, which originally has the main function to ease human life, especially in communication. The need of gadget itself become primary, especially in big cities, either in developing countries or developed countries.

By 2015, the number of smart phone users in Indonesia reached 281.9 million people. Research by Google Indonesia 2015 stated that $61 \%$ urban communities in Indonesia using gadget with total times up to 5 hours per day. This high dependency against gadget also occurs in family environment and it can cause various effects.

Excessive behaviour in using the gadget can make a person become isolated from their social environment, including their family. Family is where a person's first social interaction takes place and built through togetherness. In family, parents are the role model and set an example and also have a responsibility to establish good communication. The excessively use of gadgets among the parents could lead to behaviour change of communication and interactions between family members. These changes produce a more individualist attitude, which resulted an incomplete role of emotional and social contacts (Lestari, Riana, Taftarzani, 2016:206). Also, communication and interaction within the family is important to form a bond between parents and children as well as affect the communication of a person against the surrounding environment (Smith et al in McGrath, 2012).

By 2015, AVG Technologies conducted a survey by 2015 to find out what child feels when their parents use their gadgets in front of them. As a result, 54\% of children feel their parents too often checking his gadget, and 32\% feel unnoticed when parents are distracted by gadgets be- fore them. Parents who are too intense use gadgets in front of his children can make a child feel unnoticed, even can raises the feeling that gadgets are more important than them. The results of this survey simply becomes a picture against the phenomenon of the use of gadgets, including in Indonesia.

If this behaviour keep left without given the understanding of the harms of excessive use, it could be the users of the gadget will be increasingly difficult to interact in the real (face-to-face) with his family. It can affect the overall function of the family as the first groups that make up the personality of the person as well as the effect on the pattern of family communication (Lestari, Riana, Taftarzani, 2016:205-206).

Therefore it takes a design campaign to raises awareness by giving an understanding on parents to be wiser in using gadgets when interacting with their children.

\section{Theoretical Background}

A campaign activity is complex and mutually coordinated (Moriarty dkk, 2011:652). According to Marc Andrews in Social Campaigns Art of Visual Persuation, Its psychology, 
its semiotics, its rhetoric, (2008:16) the purpose of the campaign is to affect the three aspects of the human cognitive system, which is: (1) knowledge: give new knowledge, extend, improve and differentiate from the knowledge that had been known before, (2) attitudes: strengthen or change undesirable attitudes became a desirable attitude or expected, (3) behaviour: reinforcement of existing behaviour or changing the behaviour.

A creative brief is a guideline used to find creative concepts (Moriarty, 2011:436). According to Moriarty et al (2011:134), facet model of effects is the communication strategy method that builds the holistic effect (incurring the impression) as well as creating an integrated perception. There are six things that became the primary focus toward the consumer response. (1) Perception, the aim is to draw attention to campaign against targets that is done. Their motive is interest/relevance, selection, attention, awareness, recognition, and exposure. (2) Emotion, stimulate to induce feelings of interested or other feelings. Their motive is a feeling, a desire/hope, joy, and resonance. (3) Cognition, is a rational response to a target, where they will be looking for information or respond to information to learn and understand something. Their motive is differentiation, memory retention, learning, and cognitive needs. (4) Association, is to attract the attention of your target audience and evoke an association or relationship communications against campaign through certain symbols. Their motive is transforming, learning, as well as symbolism. (5) Persuasion, is the response that creates confidence, thereby increasing awareness of something and can motivate others to believe and do something against the conviction. Their motive is loyalty, motivation, involvement, influence, confidence, and credibility of preferences (intention). (6) Behaviour, is a direct response from the target by providing direct action and interact with the campaign. Their motive is purchased, support, try, change habits and susceptibility.

Visual communication design is the art of conveying information or messages by using fine/visual language through the medium of design. The purpose of visual communication design influence, inform, to change the behaviour of the target (audience) matches a particular purpose. The aspects taken into account are the aspects of functionality, aesthetics, and various other aspects, data obtained from research, brainstorming, thinking, as well as references to pre-existing designs (Anggraini and Nathalia, 2014:15).

\section{The Research Method}

The methods used in this research is qualitative re- search methods with methods of collecting data through observation, questionnaires to the target audience, and interviews with relevant parties, as well as literature studies and field research to related issues.

\section{Results and Discussion}

The main objective of this campaign is to invite the target audience to change behaviour to be wiser using the gadget when together with their children, given a good understanding to be able to touch the emotional and rational targets in a balanced way. Thus, the purpose of communication is to be achieved is informative and persuasive. The target audience was given understanding through discussions with experts and influencers, then are persuasive, the target audience was urged to change his habits and behaviour in ac cordance with the campaign.

Communication strategies used in this campaign is through the method of Facet Model of Effects. This effect is built through approach Think/Feel/Do and create six types of consumer response, all of which work together to create a response to a campaign.

\subsection{Creative in the design brief}

What will the advertising: Provide an understanding of the impact of bad gadgets against family interaction in order to arise awareness to change attitudes more wise in to use the gadgets, especially when he was gathered with his family.

What are the attitudes and perceptions that exist to day: "Sometimes felt anyway, so busy mas-ing since disposable gadgets. But I can't also loose-leaf because fear there is important news."

What promises we need to communicate: You will be closer to the children when rangi revenue at- tention on gadgets.

Insight: Quality Time.

What is the message of this campaign: "Gadget is not your children."

Big Idea: The child's feelings.

The communication and media strategy is structured as follows.

Table 1. Communication Strategy Draft

\begin{tabular}{|l|c|c|}
\hline Purpose & Poster teaser, video, coffee cup \\
\hline Perception & $\begin{array}{c}\text { paper. } \\
\text { paign against even the } \\
\text { son felt snubbed when } \\
\text { parents are busy with } \\
\text { the gadget. } \\
\text { Gives the initial per- }\end{array}$ \\
$\begin{array}{c}\text { The response is to be } \\
\text { achieved is to make the } \\
\text { target audience feel } \\
\text { sympathy towards the } \\
\text { character "child" that is } \\
\text { in the visual campaign. }\end{array}$ & Poster teaser, print ads, video. \\
\hline &
\end{tabular}


Table 1, cont.

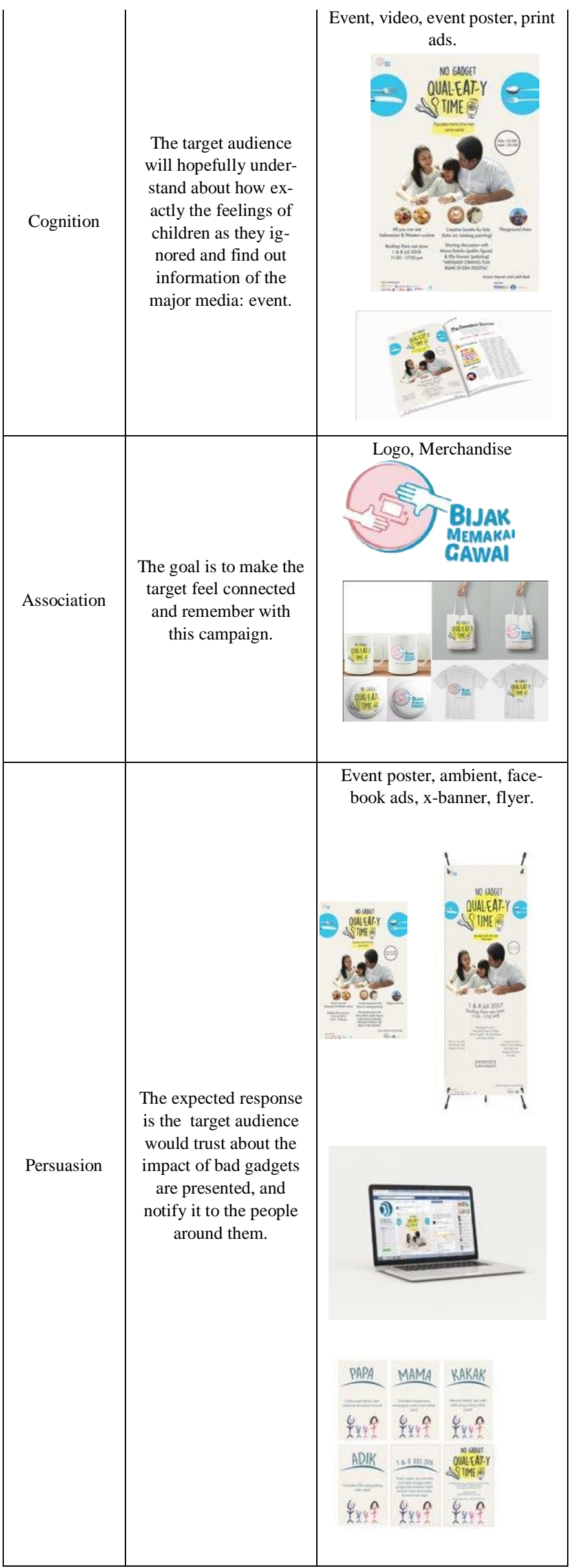

Table 1, cont.

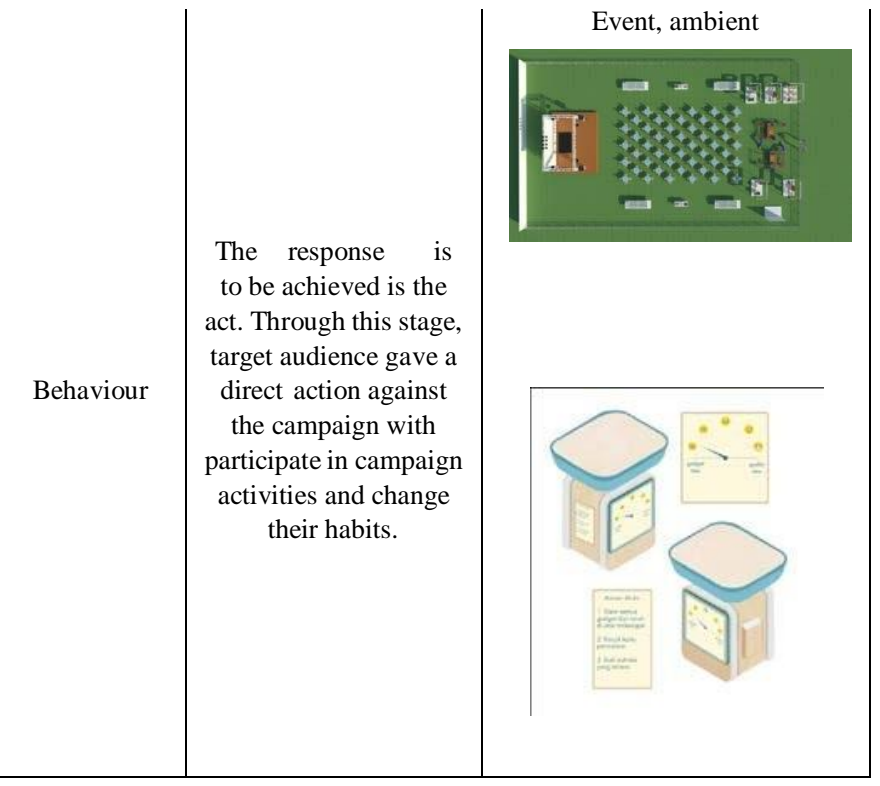

\section{Conclusion}

The campaign for this study was designed with a communication strategy that is selected is the Facet Model of Effect with creative strategies through consumer journey as well as a creative brief that produce campaigns that have a focal point in order to change the behaviour of parents saving for a moment their gadgets at the moment with them. Habits like that when implemented will pose a considerable impact to family, namely among others emotional communication so much entwined with the goods.

\section{ACKNOWLEDGEMENT(S)}

The authors wants to give appreciation for everyone who willingly helped to complete this article.

\section{REFERENCES}

[1] Inda Lestari, Agus Wahyudi Riana, dan Budi M.Taftarzani. (2016) Pengaruh Gadget pada Interaksi Sosial dalam Ke- luarga. [Online]. Available:

http://fisip.unpad.ac.id/jurnal/index.php/index/search/titles?s earchPage $=5$

[2] McGrath, S. (2012) The Impact of New Media Technologies on Social Interaction in The Household: New Media Technologies in The Household [Online].

https://www.maynoothuniversity.ie/sites/default/files/assets/ document/SiobhanMcGrath.pdf

[3] Moriarty, Mitchell, dan Wells, 2011, Advertising Edisi Kedelapan, Kencana, Jakarta

[4] Anggraini S, Lia, dan Nathalia, Kirana, 2014, Desain Komunikasi Visual : Dasardasar Panduan Untuk Pemula, Nuansa Cendekia, Bandung. 
[5] TechGuide: AVG Survey, AVG Technology, 2015 [Online] http://www.techguide.com.au/news/are-parents-spendingmor e-time-on-their-devices-than-their-kids 